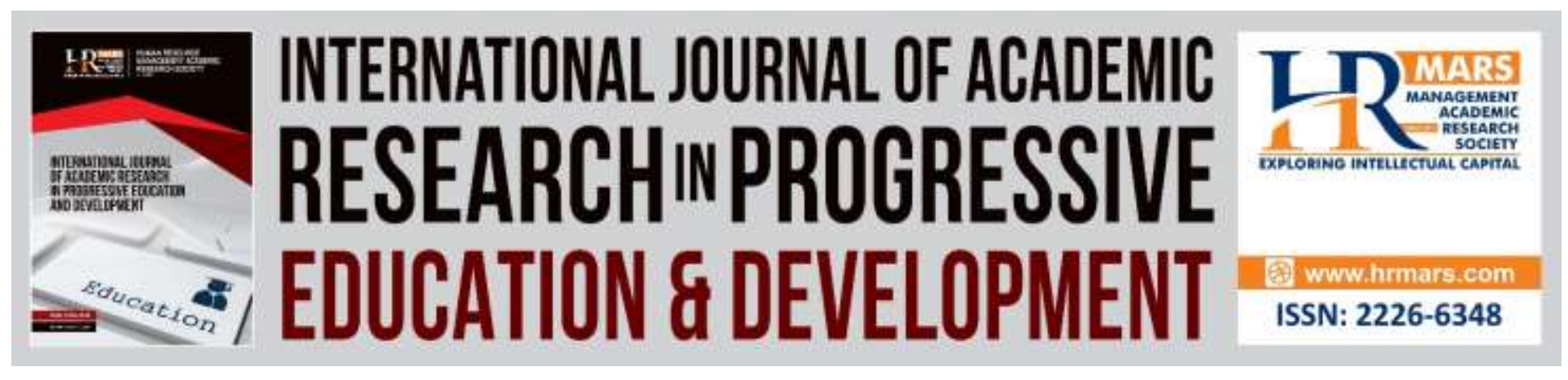

\title{
Regulating Indoor Environmental Quality (IEQ) Factors in Influencing Learning Satisfaction among Technical and Vocational Education and Training (TVET) Students
}

\author{
Mohd Hazwan Mohd Puad \& Ainul Jasmeen Ainul Zuhairi
}

To Link this Article: http://dx.doi.org/10.6007/IJARPED/v8-i4/6693

DOI:10.6007/IJARPED/v8-i4/6693

Received: 15 October 2019, Revised: 30 October 2019, Accepted: 11 November 2019

Published Online: 30 November 2019

In-Text Citation: (Puad, \& Zuhairi, 2019)

To Cite this Article: Puad, M. H. M., \& Zuhairi, A. J. A. (2019). Regulating Indoor Environmental Quality (IEQ) Factors in Influencing Learning Satisfaction among Technical and Vocational Education and Training (TVET) Students. International Journal of Academic Research in Progressive Education and Development, 8(4), 688704.

Copyright: (c) 2019 The Author(s)

Published by Human Resource Management Academic Research Society (www.hrmars.com)

This article is published under the Creative Commons Attribution (CC BY 4.0) license. Anyone may reproduce, distribute, translate and create derivative works of this article (for both commercial and non-commercial purposes), subject to full attribution to the original publication and authors. The full terms of this license may be seen at: $\underline{\text { http://creativecommons.org/licences/by/4.0/legalcode }}$

\section{Vol. 8(4) 2019, Pg. $688-704$}

Full Terms \& Conditions of access and use can be found at http://hrmars.com/index.php/pages/detail/publication-ethics 


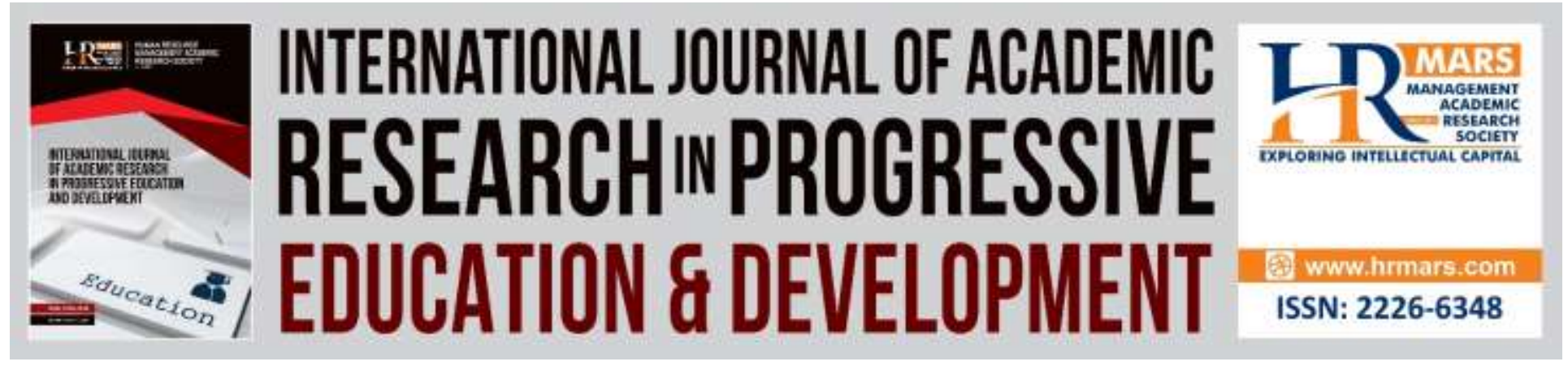

\title{
Regulating Indoor Environmental Quality (IEQ) Factors in Influencing Learning Satisfaction among Technical and Vocational Education and Training (TVET) Students
}

Mohd Hazwan Mohd Puad \& Ainul Jasmeen Ainul Zuhairi

Faculty of Educational Studies, Universiti Putra Malaysia (UPM), Serdang, Selangor, Malaysia

\begin{abstract}
Productivity and outcomes are important for Technical and Vocational Education and Training (TVET) students. There are variety of factors that can impact student productivity and outcomes, such as indoor environmental quality (IEQ). IEQ can affect to student achievement. Therefore, it is essential to know if the students are satisfied with their indoor environmental quality (IEQ). Three dimensions of IEQ, namely lighting, acoustics, and air quality were the focus of this study. This study identifies the extent of classroom or physical IEQ (lighting, acoustics, and air quality) among Technical and Vocational Education and Training (TVET) students in a polytechnic. Also, the objective of this study is to examine the association between classroom IEQ and student learning satisfaction. This is a quantitative approach and descriptive design study. The collection of data was through questionnaires, approximately 500 questionnaires distributed to the students of the TVET, namely polytechnics, students through online survey. There were 404 students answered and the response rate was $80.8 \%$. The IBM SPSS Statistics software was used to analyze the data. Descriptive and inferential statistical analysis were utilized to measure the relationship of the variables. The findings shows that the level of student learning satisfaction and the perception level of IEQ are high. The independent IEQ variables have positive correlation with learning satisfaction among TVET students.
\end{abstract}

Keywords: Indoor Environmental Quality, Learning Satisfaction, Lighting, Acoustics, Air Quality, Temperature.

\section{Introduction}

The role of education is pivotal to the country. Education plays the important role in pursuit of economic growth and national development. Education is a crucial to the country's success and a fundamental right for the progress of the nation (United Nations Educational, Scientific, and Cultural Organization (UNESCO), 2019). Based on the Malaysia Education Blueprint 2013-2025, the effort to improve students' overall achievement is crucial for the country in uprising our local education towards international standards (Ministry of Education Malaysia, 
2019). According to the Blueprint, it was stated by the international student assessments that the academic achievement of Malaysian students is decreasing, when directly compared to the quality of educational outcomes across different nations. Thus, it is the main objectives to maximize student outcomes in order to achieve high efficiency and effectiveness in education.

To support the nation's objective for education which is to maximize student outcomes, it is vital for the learning environment of students in education institutions to be in a satisfactory quality and condition. This is because good quality of environment is a catalyst for positive environment for learning which is important in producing quality students in line with the vision and mission of the nation. Moreover, to support this statement, there were similar studies stated that student satisfaction is positively related to achievement (Durodola \& Ajayi, 2015; Ko \& Chung, 2014). Once students feel satisfied with their environment, better outcome can be achieved afterwards. Therefore, student learning satisfaction is also able to be used as an indication to measure students' learning achievement inside and outside classroom (Chang \& Chang, 2012).

Moreover, the quality of environment is one of the important elements and as the indicator of the effectiveness of students' achievement in terms of academic and non-academic. Thus, for this study, the environment aspect focuses on the environment in the classroom. Additionally, good indoor environmental quality promotes healthy learning environment for students as well as increase their productivity (Fisk, 2002; Singh, 2013).

Indoor environmental quality (IEQ) is also one of the criteria in the Malaysia Green Building Index $(\mathrm{GBI})$, a green rating tool for man-made buildings and premises, to inspire sustainability culture. In order to promote sustainability in the built environment, polytechnic which is one of the educational institutions for Technical Vocational Education and Training (TVET), is currently in an effort to exercise green practices. According to the blueprint, the strategic direction and the continuous implementation of green technology practices in polytechnics is important in shaping the next generation of workers who are sensitive to environmental issues. In the context of TVET, the implementation plan will consolidate green initiatives in teaching and learning aspects which is Green Campus.

For TVET, Shift 4 in the Malaysia Education Blueprint 2013-2025 (Higher Education) aims to nurture and produce quality TVET graduates. However, in producing quality TVET graduates, there are no particular strategies within the shift that emphasize on the importance of educational environmental quality towards producing quality students. Furthermore, student learning satisfaction can assist in cultivating and regulating better learning institutions (Bolliger \& Martindale, 2004; Wu, Hsia, Liao \& Tennyson, 2008).

Nevertheless, there are limited studies has been done in relation with physical environmental elements and education, focusing on IEQ and student learning satisfaction for Malaysian TVET students. Although there were research on IEQ have been conducted at educational institutions, to the researchers' reviews, there is unlikely extensive studies have been carried out in higher education such as polytechnic settings. Hence, it is relevant and justifiable gap. Thus, this study is executed to make the gap closer. The study investigates the perception level of indoor environmental quality (IEQ) and student learning satisfaction. Since student satisfaction could affect student learning outcomes, this study is parallel with the Malaysia education objective in the blueprint (Durodola \& Ajayi, 2015; Ko \& Chung, 2014). 


\section{Student Learning Satisfaction Improves Educational Institution}

Satisfaction, as discussed by Flammger (1991) and Martin (1988), can be defined as the needs to realize rationally, to fulfill with pleasure, and to feel sufficiently. Those feelings and emotions are situated between the expectation and actual experience. If the situation and the real experience is the same to or better than a person's expectation, he or she feels satisfied. In contrast, if the situation and actual experience is worse than expectation, individual feels dissatisfied. In this study, the researchers set that satisfaction is the perception or attitudes of students towards learning activities (Tough, 1982; Huang, 2014).

On the other hand, according to Borden (1995), student learning satisfaction is resulting from the connection between the priorities of student, or what is important to students, and the environment of educational institution. According to Chang and Chang (2012), learning satisfaction is a guide to appraise students' learning achievement and essential as teaching quality indicators. Schreiner and Juillerat (1994) mentioned that student learning satisfaction is the extent to which a student's perceived educational experience meets their expectations or exceeds it, measured as gaps between expectation of students and perceived reality.

In this study, the student learning satisfaction variable can be explained by the sum of student feelings or perception that results from the satisfaction of the indoor environmental quality (IEQ) of their classroom. There are a number of theories of the psychosocial dynamics of student learning satisfaction. One of the theories is the "happy-productive" student theory by Cotton, Dollard, and de Jonge (2002). The theory points that student learning satisfaction is dependent to the psychosocial factors that includes well-being, coping and stress. The theory also explained that at university and college, high level of psychological distress associated to lower level of satisfaction.

Another theory on student learning satisfaction is developed by Hatcher, Prus, Kryter and Fitzgerald (1992), namely the Investment-Model. The theory demonstrates the relationship between academic performance and student satisfaction. Whenever the reward of study increased, student learning satisfaction will also be increased as well. One of the ways to improve student outcomes, universities need to prioritize the satisfaction needs of students (Hatcher, Kryter, Prus, and Fitzgerald, 1992).

\section{Indoor Environmental Quality (IEQ) Promotes Student Performances}

The elements of physical quality environment is broad. It includes lighting, acoustics, temperature, and air quality. According to Cheryan, Ziegler, Plaut and Meltzoff (2014), classroom physical environment factors can also be known as the classroom's facilities. The classroom facilities are imperative to student success and need to be correctly addressed to create the most suitable spaces for student learning because physical environments has an impact on student achievement.

Indoor environmental quality (IEQ) or classroom facility, based on Mendell and Heath (2005), is the quality of a building's physical environment in the aspects of four factors: lighting, temperature, air quality and acoustics comfort. Moreover, according to Shell (2015), IEQ refers to the capability of a building's physical environment to promote the health as well as happiness of its occupants. According to Singh (2013), healthy learning environments for students with good 
indoor environmental quality can significantly affect student's ability to perform tasks that requires concentration. It is also stated that the relationship between good indoor environmental quality leads to better performance and well-being of students. It can be concluded that students feel satisfied with their indoor environmental quality which supports their health, can achieve better outcome. In this study, IEQ is defined as the quality of physical environment which are lighting, acoustic, temperature and air quality in the classroom.

Samani and Samani (2012) viewed that sufficient lighting is highly recommended for reading as well as other visual-based tasks, especially the task that requires details and focus. Aligned with physical and psychological aspects, the purpose of lighting is to supply appropriate illuminance, so eyes have enough amount of light to translate what they face on. Based on experts, for better lighting quality in classrooms, the integration of two types of lighting which are the daylighting and artificial lighting is recommended. Although the eye can adapt to variations in brightness of lighting, too much brightness will result to visual stress as well (Lechner, 2014). By providing large quantities of light, it does not necessarily makes a good lighting environment and not suitable for performing visual tasks. The appropriate amount of light that forms a good lighting environment is essential for satisfying aesthetic and biological needs.

Noise is considered to have an influence on psychology, human behavior and student performance. Chiang and Lai (2008) identified negative effects of working in a noisy room. The result of the study shows that the acoustic environment of the elementary schools is inadequate and noise affected learning outcomes as well as health of the children.

According to Shell (2015), acoustic is the condition or environment that is "related to sound pressure waves by the sensitivity of human hearing" (p. 15). According to Zannin, Passero, and Zwirtes (2012), the noise levels inside and outside of the classroom can characterize the quality of acoustic. Based on the research by Zannin and Zwirtes (2009), educational institutions built in 1977-2005 are always be compared as recommended standard designs for school buildings. Zannin and Zwirtes found that noise interference causes classrooms to be uncomfortable places for learning and studying. The teaching and learning process can be hindered by excessive external unwanted sound or noise (Klatte, Bergstroem \& Lachmann, 2013).

Another IEQ element is environmental temperature. Whenever the environmental temperature is above $37^{\circ} \mathrm{C}$, the heat flow reverses and the body gains heat from the air. Consequently, the increase of temperature presents challenges in occupants' satisfaction as well. The comfort range of environment for normal people is around $25^{\circ} \mathrm{C}$ and it is called as normal room temperature. A high temperature greater than $25^{\circ} \mathrm{C}$ are normally considered as not satisfying and results in poor air quality (Kabanshi, Wigo, Ljung \& Sorqvist, 2016; Lechner, 2014). Amirul et al. (2013) claimed that student's focus during learning time can be affected by excessive cold temperature or heat in the learning environment. Temperature needs to be compatible or appropriate with learning activities that takes place in the classrooms. Hence, today, the learning environment, such as classrooms, should be equipped with temperature control devices, thermostat, to enable the room temperature to be controlled in accordance to the teaching and learning needs of students.

Indoor air quality according to Awang, Mahyuddin, and Kamaruzzaman (2015) denotes the quality of air inside a building. Indoor air quality refers to the pollutants that were produced 
and take place inside a building. According to Wark and Warner (1981), indoor air pollution is caused by the combination of effects from factors of physical, chemical, and biological as well as inadequate ventilation in the indoor environment. In addition, the sources of air pollution inside a building can be sourced from heating, ventilation, air conditioning systems, building equipment, furnishings, and human activities. According to Jurado, Bankoff, and Sanchez (2014) they suggested that good indoor air quality must be controlled because people spend most of their time which is more than $90 \%$ of their time being indoors. Learning environment should have a good indoor air quality in ensuring learning process to take place smoothly. To achieve a well teaching and learning process, indoor air quality needs to be optimized according to the needs of teachers and students (Amirul et al., 2013). Amirul et al. (2013) found out that high level of humidity may contribute to health problems among students. Therefore, the air humidity in the classrooms needs to be in control and good conditions. Additionally, the learning environment must be carefully planned and designed so that the building is not positioned near water resources or water flow to make certain no formation of water retention which may contribute to high humidity to the learning environment. Other than that, in and out air flow of classrooms should effectively occur besides providing sufficient number of windows. For this study, the researchers utilized the term air quality based on the students' sense in detecting the factors that caused their discomfort, physically or psychologically, that relates to air circulation and the presence of unpleasant smell.

\section{Indoor Environmental Quality (IEQ) and Student Learning Satisfaction}

A study by Durodola and Ajayi (2015) was conducted to evaluate student learning satisfaction with classroom facilities which includes physical environment such as lighting, temperature and acoustic in private universities. They found out that there is a relationship between physical environment and student performance. According to Ko and Chung (2014), there was a positive relationship between learning satisfaction of students and student performance. If students have good learning satisfaction, then they will have good academic performance.

According to Hanssen and Solvoll (2015), student perception on temperature, acoustic and lighting of the physical environment positively associated with overall learning satisfaction. Another study also proven that quality of indoor environment contributes to student learning satisfaction (Vidalakis, Sun \& Papa, 2013). Further study by Choi et al. (2014) proves that there is significant evidence that indoor environment factors such as thermal, acoustic and lighting is associated with positive outcomes of students which includes overall satisfaction with learning and classroom environment.

In addition, Lopez del Puerto (2009) conducted a study at a graduate school on student learning satisfaction. The results show that there is a relationship between physical environment factors and student learning satisfaction. Furthermore, according to Chang (2011), if students come across problems, they would also affect their satisfaction. Chokor (2015) viewed that thermal comfort and acoustic quality, and similar performance in lighting level, indoor air quality does affect the overall satisfaction on the facilities. The average levels of satisfaction that have better facilities and adequate overall environment is higher than building that were not designed to meet the requirements of a good IEQ. 
Vol. 8, No. 4, 2019, E-ISSN: 2226-6348 @ 2019 HRMARS

There was a similar study, investigated by Lee (2007) for office IEQ based on criteria that included office layout quality, office furnishings quality, lighting quality, acoustics quality, and cleanliness and maintenance quality. The results of the study indicated that acoustic quality and thermal comfort which includes temperature and air quality showed the lowest satisfaction by the workers. In addition, findings by Shell (2015) with this study suggested that differences in the physical environment namely temperature, acoustics, lighting and air quality correspond to satisfaction with indoor environmental quality.

A study by Samani and Samani (2012) identified the influence of indoor lighting on students' learning performance. It is important to improve lighting in learning environments in order to improve students' learning performance because lighting quality has significance affect over students' learning performance. Ko and Chung (2014) concluded that lighting affects student learning satisfaction.

A sufficient quality of lighting assists students to focus on their learning by making them feel more relaxing and does not make them sleepy. Thus, good quality lighting system will lead students to have better learning outcomes and performances. A study found out lighting and acoustics of the physical environment does influence student performance (Tanner, 2009). Moreover, Choi et al. (2014) agreed that lighting is related to student satisfaction and learning as well as classroom environment. Yang, Becerik-Gerber and Mino (2013), conducted a study on impact of classroom attributes on student learning satisfaction. In their study, it was discovered that acoustics gives significant impact on the performances of students. Moreover, since student performance and student satisfaction share a significant relationship, acoustics factor can also have impact on student learning satisfaction (Ko \& Chung, 2014). According to Awang, Mahyuddin and Kamaruzzaman (2015), acoustics are the most contributing factor to student dissatisfaction.

Previous studies show that acoustic also affects students learning that could give an impact on their learning performance (Lewinski, 2015). Lewis mentioned that acoustics significantly affect student learning the most. Students are prevented from focusing on their tasks due to the distracting environment or noise. Thus, it will affect and influence negatively on student performance. Tanner (2009) and Hanssen and Solvoll (2015) agreed that acoustics does influence student performance as well as positively related with their overall satisfaction.

Lewinski (2015) also indicates that temperature must be maintained at a comfortable level to get optimum learning outcomes. Failure to maintain the temperature gives an impact on student performance, including behavior, psychology and attitudes. Durodola and Ajayi (2015) suggest a relationship between temperature and student performance. Student performance is positively related to learning satisfaction. It can be learnt that temperature can also affect student learning satisfaction as well as positively related to their overall learning satisfaction (Hanssen and Solvoll, 2015).

In addition, $\mathrm{Gu}$ (2011) mentioned that the performance of building occupants is dependent on indoor environment factors including air quality. Student performance and environmental factors have a positive relationship with learning satisfaction. It can be assumed that air quality can also affect student satisfaction. According to Schneider (2002) higher ventilation rates increase learning rate, while poor air quality reduces occupant health and leading to greater absenteeism as well as lower student achievement. 
Open Systems Theory by Katz and Kahn (1978) refers to the concept that organizations are strongly influenced by their environment (Figure 1). The environment consists of factors that apply various forces to people. In educational organizations, the input can be associated with students that are enrolling to the institutions. They are then exposed with the environment of their learning institutions which is the physical environment of their classroom. Later, the output which is the outcomes of the students will be affected by the environment they were in. This concept shows that IEQ which is the physical environment can influence students' outcomes, such as student learning satisfaction.

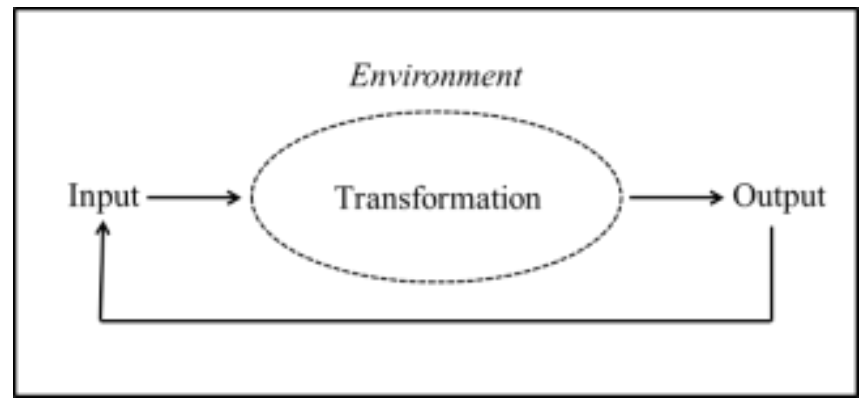

Figure 1: Open Systems Theory

\section{Research Methodology and Findings}

The design of this study is a quantitative and descriptive by using a questionnaire instrument. Descriptive data were analyzed by using IBM SPSS Statistics software. The population of this study was students in Politeknik Sultan Salahuddin Abdul Aziz Shah, Shah Alam, Selangor, Malaysia. The sampling technique is convenience sampling which involve 404 students.

A set of questionnaire was developed as the instrument to gather the data based upon the research questions. Section A comprises of questionnaire about student learning satisfaction of classroom indoor environmental quality. There are six items in this section and measured by using 6-point Likert Scale from 1 = Very Dissatisfied, 2 = Dissatisfied, 3 = Slightly Dissatisfied, $4=$ Slightly Satisfied, $5=$ Satisfied, and $6=$ Very Satisfied. Section B consists of questions related to the classroom IEQ. There are 19 items in this section. Respondents were asked to choose the appropriate number that represents the response for each of the issues raised by the 6-point Likert scale. All of the measurement items for this section were in 6-point Likert Scale from $1=$ Strongly Disagree, 2 = Disagree, 3 = Slightly Disagree, 4 = Slightly Agree, 5 = Agree, and 6 = Strongly Agree. Section $\mathrm{C}$ collects data on the demographic information of the respondents. A pilot test was conducted on 35 students. These students are excluded from the actual data collection. The Cronbach's Alpha values for student learning satisfaction (.89), temperature (.91), lighting (.78), acoustics (.72), and air quality (.79) were considered good and acceptable.

The findings in Table 1 shows the demographic information of respondents in this study. For age of the respondents, the majority of respondents (43.3\%) are aged between 20 to 22 years old, followed by 116 respondents (28.7\%) aged 25 years and above. Lastly, there were 113 respondents (28.0\%) are aged between $23-24$ years old. For the gender of the respondents, 331 respondents (81.9\%) were female while 73 respondents $(18.1 \%)$ were male students. About 110 respondents $(27.2 \%)$ were in the fourth semester. This is followed by 94 respondents $(23.3 \%)$ in 
INTERNATIONAL JOURNAL OF ACADEMIC RESEARCH IN PROGRESSIVE EDUCATION AND DEVELOPMENT

Vol. 8, No. 4, 2019, E-ISSN: 2226-6348 @ 2019 HRMARS

the third semester, 76 respondents $(18.8 \%)$ in the fifth semester, 53 respondents $(13.1 \%)$ in the second semester, 42 respondents (10.4\%) in the first semester, 16 respondents (3.8\%) form other semesters and lastly 13 respondents of semester $6(3.2 \%)$.

Table 1: Demographic information ( $\mathrm{N}=404)$

\begin{tabular}{ccc}
\hline \multicolumn{1}{c}{ Demography } & Frequency & Percentage (\%) \\
\hline Age & & \\
Below 20 years old & 0 & 0.0 \\
20-22 years old & 175 & 43.3 \\
23-24 years old & 113 & 28.0 \\
$\quad$ Above 25 years old & 116 & 28.7 \\
Gender & & \\
Male & 73 & 18.1 \\
$\quad$ Female & 331 & 81.9 \\
Semester & & \\
1 & 42 & 10.4 \\
2 & 53 & 13.1 \\
3 & 94 & 23.3 \\
4 & 110 & 27.2 \\
5 & 76 & 18.8 \\
6 & 13 & 3.2 \\
Others & 16 & 3.8 \\
Sitting Location & & \\
Front & 119 & 29.5 \\
Middle & 221 & 54.7 \\
Back & 64 & 15.8 \\
Disabilities & & \\
Yes & 307 & 76.0 \\
No & 97 & 24.0 \\
\hline
\end{tabular}

For the sitting location of the respondents, the result shows that majority of the respondents which are 221 students (54.7\%) usually sit in the middle of the classroom. This is followed by 119 respondents $(29.5 \%)$ that usually sit at the front of the classrooms and the rest is at the back which is 64 respondents (15.8\%). Table 1 also indicates that 97 respondents $(24.0 \%)$ don't have any disability while 307 respondents (24.0\%) have disabilities regarding vision, hearing or other disabilities that may affect the respondent's perception of the classroom environment.

\section{Factor Analysis}

Two factor analyses were conducted separately for independent variables (lighting, acoustics, temperature and air quality) and dependent variable (student learning satisfaction). Only items with a loading 0.50 and above were considered. Consequently, the clean factors were then interpreted by examining the largest values linking the factors to the items in the rotated factor matrix. The factor loading for the independent variables is shown in Table 2 and for the 
INTERNATIONAL JOURNAL OF ACADEMIC RESEARCH IN PROGRESSIVE EDUCATION AND DEVELOPMENT

Vol. 8, No. 4, 2019, E-ISSN: 2226-6348 @ 2019 HRMARS

dependent variable in Table 3.

Table 2: Factor Analysis for Independent Variables

\begin{tabular}{lcc}
\hline & Component \\
Item & $\mathbf{1}$ \\
\hline DV2 & .78 \\
DV4 & .78 \\
DV3 & .77 \\
DV5 & .74 \\
DV6 & .74 \\
\hline
\end{tabular}

For independent variables, the results show the KMO value of .92; indicating that the data was normal because the KMO value was greater than 0.60 . Then, the Bartlett's test of Sphericity was highly significant with the value of $p<.05$. For dependent variable, the results show the KMO value of .844 indicating that the data was normal as the KMO value was greater than 0.60 and the Bartlett's test of Sphericity was highly significant with the value of $p<.05$. The findings show that there was no item needed to be deleted as there were no high cross loading and fall under different components in the sense that it matched the proposed concepts. However, it was found that air quality scale and temperature scale fell under the same factor. Then, TEMP1, TEMP2, TEMP3 and TEMP4 were dropped from independent variables of this research.

\begin{tabular}{|c|c|c|c|}
\hline \multirow{2}{*}{ Item } & \multicolumn{3}{|c|}{ Component } \\
\hline & 1 & 2 & 3 \\
\hline TEMP2 & .82 & & \\
\hline TEMP4 & .82 & & \\
\hline TEMP3 & .78 & & \\
\hline AIR3 & .70 & & \\
\hline AIRZ & .69 & & \\
\hline AIR1 & .69 & & \\
\hline TEMP1 & .69 & & \\
\hline LGHT3 & & .78 & \\
\hline UGHT4 & & .77 & \\
\hline UGHT2 & & .76 & \\
\hline UGHT1 & & .75 & \\
\hline UGHT5 & & .75 & \\
\hline UGHT6 & & .73 & \\
\hline LIGHT7 & & .68 & \\
\hline ACOUS1 & & & .73 \\
\hline ACOUS2 & & & .72 \\
\hline ACOUS3 & & & .66 \\
\hline
\end{tabular}

\section{Descriptive Analysis of IEQ and Student Learning Satisfaction}

The results of mean and standard deviation of all IEQs and student learning satisfaction are shown in Table 4 for acoustics, Table 5 for lighting, Table 6 for air quality and Table 7 for student learning satisfaction. An analysis of Pearson correlation was used to measure the relationship between lighting, acoustics, and air quality with student learning satisfaction. Table 


\section{INTERNATIONAL JOURNAL OF ACADEMIC RESEARCH IN PROGRESSIVE EDUCATION AND DEVELOPMENT}

Vol. 8, No. 4, 2019, E-ISSN: 2226-6348 C 2019 HRMARS

8 shows all variables have positive correlation. The first dimension of indoor environmental quality is lighting. As shown in Table 8 , it can be seen that the correlation between lighting and student learning satisfaction is $(r=.77, p=0.01)$ which indicates that there is a positive, large and significant relationship between the quality of lighting and student learning satisfaction. The second dimension is acoustics. It can be seen that the correlation between lighting and student learning satisfaction is $(r=.48, p=0.01)$. It indicates that there was a medium, positive correlation between the quality of acoustics and student learning satisfaction. The result of air quality with $(r=.72, p=0.01)$ shows that there is a positive, large and significant relationship between air quality and student learning satisfaction.

Table 4: Descriptive of Acoustics ( $N=404)$

\begin{tabular}{lcc}
\hline \multicolumn{1}{c}{ Item } & Mean (M) & Standard Deviation (SD) \\
\hline $\begin{array}{l}\text { My classrooms have an appropriate sound privacy (conversations without neighbors } \\
\text { overhearing and not overhear neighbors). }\end{array}$ & 3.19 & 1.37 \\
I am able to hear desired sounds in my classrooms. & 4.15 & 1.16 \\
I am able to limit distraction from undesired sounds in my classrooms. & 4.18 & 1.06 \\
\hline \multicolumn{1}{c}{ Total } & $\mathbf{3 . 8 4}$ & $\mathbf{0 . 7 5}$ \\
\hline
\end{tabular}

Table 5: Descriptive of Lighting ( $\mathrm{N}=404)$

\begin{tabular}{lcc}
\hline \multicolumn{1}{c}{ Item } & Mean (M) & Standard Deviation (SD) \\
\hline My classrooms have an adequate overall lighting (electric and daylighting). & 4.53 & 0.90 \\
My classrooms have adequate overall electric lighting. & 4.58 & 0.90 \\
My classrooms have adequate overall daylighting. & 4.28 & 1.01 \\
My classrooms have adequate overall visual comfort of the electric or daylighting & 4.28 & 0.90 \\
(glare, reflections, contrast). & 4.33 & 0.90 \\
The contrast due to electric or daylighting in my classrooms is appropriate. & 3.67 & 1.20 \\
My classrooms have an adequate quantity of electric lighting. & 3.49 & 1.25 \\
My classrooms have an adequate quantity of daylighting. & 4.17 & 0.67 \\
\hline
\end{tabular}

\begin{tabular}{lcc}
\multicolumn{1}{c}{ Table 6: Descriptive of Air Quality ( $N=404)$} & \\
\hline \multicolumn{1}{c}{ Item } & Mean (M) & Standard Deviation (SD) \\
\hline $\begin{array}{l}\text { My classrooms have an adequate overall indoor air quality (free of odors, staleness, } \\
\text { chemicals, or irritants). }\end{array}$ & 4.34 & 0.99 \\
My classrooms have an adequate humidity (not too dry or too moist). & 4.38 & 0.92 \\
My classrooms have an adequate air velocity (drafty or stagnant). & 4.29 & 0.90 \\
\hline Total & 4.34 & 0.85 \\
\hline
\end{tabular}

\section{Discussion, Conclusion and Recommendation}

The majority of respondents' ages were ranged between 20 - 22 years old and most of them were female. Moreover, majority of the respondents were in the fourth semester. For the respondent's general sitting location, the most common general sitting location is in the in the middle of the classroom. It also can be concluded that most of the respondents have disabilities regarding vision that mostly comprises of long-slightness and short-sightedness. There were also disabilities regarding hearing such as hearing impairment or other disabilities that may affect the 
Vol. 8, No. 4, 2019, E-ISSN: 2226-6348 @ 2019 HRMARS

respondent's perception of the classroom environment.

The results showed that all the dimensions for IEQ which includes lighting, acoustics, and air quality had high scores. However, air quality had the highest scores ( $M=4.17, S D=0.67$ ) among the other dimensions in the independent variables. Thus, it can be concluded that lighting received high level of agreement from respondents compared to other dimensions in the independent variables.

Table 7: Descriptive of Student Learning Satisfaction ( $\mathrm{N}=404)$

\begin{tabular}{lcc}
\hline \multicolumn{1}{c}{ Item } & Mean (M) & Standard Deviation (SD) \\
\hline $\begin{array}{l}\text { The overall thermal comfort conditions in my classrooms [thermal conditions are } \\
\text { defined as temperature (hot or cold), air velocity (drafty or stagnant) and humidity (dry }\end{array}$ & 4.47 & 0.85 \\
or moist)]. & 4.48 & 0.94 \\
The overall indoor air quality conditions in my classrooms. (Indoor air quality is defined \\
$\begin{array}{l}\text { as the absence of odors, stale or stagnant air, or other air-borne chemical or irritants.) } \\
\text { The overall acoustic quality in my classrooms. (No noisy equipment, echo, ability to }\end{array}$ \\
$\begin{array}{l}\text { hear instructor). } \\
\text { The overall lighting conditions in my classrooms. }\end{array}$ \\
$\begin{array}{l}\text { My ability to see the presenter in my classrooms. } \\
\text { My ability to see materials presented in my classrooms. }\end{array}$ \\
\hline
\end{tabular}

$+$

Table 8: Pearson Correlation Analysis ( $\mathrm{N}=404)$

\begin{tabular}{lccc}
\hline & Air Quality & Lighting & Acoustics \\
\hline Student Learning Satisfaction & 0.72 & 0.77 & 0.48 \\
\hline
\end{tabular}

It was found that there was a relationship between classroom IEQ and student learning satisfaction among the students at the polytechnic. This means that lighting, acoustics and air quality has a positive relationship with student learning satisfaction. For lighting, majority of the students were slightly agreed with the adequacy of overall electric lighting in their classroom. It is then followed by adequacy of the overall lighting which includes both electric and daylighting. Consequently, the quantity of electrical lighting and the contrast due to electric lighting or daylighting in their classrooms is appropriate. This shows that lighting affects students and it can be concluded that the quantity and quality of overall electrical and daylighting fulfil the students' satisfaction. Moreover, based on the findings, there was a positive relationship between the quality of lighting and student learning satisfaction. Similar to study by Samani and Samani (2012), lighting has affected on student performance positively. Since student performance influence student learning satisfaction (Ko \& Chung, 2014), it can be summarized that lighting can also influence student learning satisfaction. The quality of lighting is important for students because according to Lechner (2014), lighting is necessary for performing certain visual tasks, it is also essential in satisfying the biological needs of students such as the need for students to focus on activities and many more. Moreover, Samani and Samani (2012) also suggest that people require enough and appropriate quantity of lighting for reading and doing other visual tasks. 
Vol. 8, No. 4, 2019, E-ISSN: 2226-6348 @ 2019 HRMARS

For the second dimension which is acoustics, it can be concluded that most of the classrooms have an appropriate sound privacy. Appropriate sound privacy means the classrooms are quiet and suitable of the students to study because they have their privacy from noise interference, for instance the students can have conversations in their classrooms without the neighboring classrooms overhearing and for the students themselves not to overhear their neighboring classrooms. Students are also able to hear desired sound, such as lecture from the lecturers or during presentations in their classrooms. This is the reason the students feel satisfied with the acoustics in their classrooms.

Furthermore, the research findings revealed that there was a positive correlation between the quality of acoustics and student learning satisfaction. Similarly, Yang, BecerikGerber and Mino (2013) and Lewinski (2015) found that students believe on the concept of acoustics in giving significant impact on student learning, which is student learning satisfaction (Ko \& Chung, 2014). The quality of acoustics is important for student satisfaction because, according to Zannin and Zwirtes (2009), the noise that interfere students during learning will make their classrooms as uncomfortable places. It will also hinder the students' focuses and thus will make them feel unsatisfied. Supported by Klatte, Bergstroem and Lachmann (2013), teaching and learning process can be hindered by excessive external and unwanted sound. Therefore, it is important to ensure classrooms have a good quality of acoustics with appropriate sound privacy.

For the third dimension which is air quality, the respondents agreed that their classrooms have an adequate humidity, which means the air condition in their classrooms is neither too dry nor too moist for their satisfaction. Their classrooms correspondingly have an adequate overall indoor quality which means they are free of unwanted odors or unpleasant smell, staleness of air, chemicals or irritants. It can be summarized that the air quality of the classrooms fulfill student learning satisfaction. Additionally, there was positive relationship between air quality and student learning satisfaction based on the findings of this study. Since temperature and air quality falls under the same factor, there is an evidence that temperature has a positive relationship with students' overall learning satisfaction (Hanssen \& Solvoll, 2015). Air quality is important with student learning satisfaction since there are many factors that contribute to students' discomfort related to air circulation and the presence of unpleasant odor (Ainul Jasmeen Ainul Zuhairi \& Mohd Hazwan Mohd Puad, 2016; Awang et al., 2015).

There are recommendations and considerations that can be implemented for future research in examining the relationship between classroom IEQ and student learning satisfaction:

1. Since lighting had received high level of agreement among the students, it can be said that students are more satisfied with the quality of lighting in their classrooms. However, while overall quantity of electrical lighting is good, the overall quantity of daylight in the classrooms should be improved. According to Samani and Samani (2012), the integration of daylighting and artificial lighting (electrical lighting) in classrooms is recommended in order to produce better and quality lighting for students' environment. Also, higher ceilings can lower the reduction of the amount of daylight available in the classrooms.

2. On the other hand, McCreery and Hill (2005) suggested that ceiling configurations are capable in creating an even distribution of light within a room. Moreover, if appropriate 
daylighting techniques are used to displace electrical lighting the saving for lighting can be dramatic. Visual comfort of the electric or daylighting due to reflections, glare and contrast correspondingly should be considered. According to McCreery and Hill (2005), whiteboards and video monitors that causes glare is also one of a factor. A good lighting design will be taken into account the location of these components within the room, and their positions to avoid reflected glare from highly contrasting sources.

3. The acoustics can be improved more. If possible, undesired sounds should be limited or controlled, so that students can be more focused in class. According to Zannin, Passero, and Zwirtes (2012), the level of noise from inside and outside of the classroom can be controlled by the installation of sound insulation.

4. The classroom temperatures need to be controlled so that it is consistent throughout the classrooms. This means that the temperature is neither too hot nor too cold throughout the classroom during teaching and learning procedures. If the temperatures of classrooms are consistent, students will be more satisfied. Good ventilation system can control temperature besides humidity. It can distribute adequate amount of air as well as remove pollutants (Jurado, Bankoff \& Sanchez, 2014).

The recommendations for future research are as follows:

1. It is highly recommended that a similar study be conducted using simple random sampling since the present study was conducted using convenience sampling that limited the study to be generalized to the whole population.

2. The present study measure of indoor environmental quality was based on student perception on their classroom environment by using survey. A study that can run tests using on-site measurements is more recommended. Some of the tools that can be used are Light Meter (to measure the level of lighting), Sound Level Meter (to measure the level of sound and noise), Air Velocity Meter (to measure the air flow inside of building), Relative Humidity Probes (to determine the temperature relative humidity), and Carbon Dioxide Probe (to measure carbon dioxide concentration inside the building).

3. In the future, a similar study can be conducted at a private institution of higher education since the present study was conducted at a public institution. This is to identify whether there are similarities in the findings on the association between classroom IEQ and student learning satisfaction between public and private educational institutions.

4. The use of moderating or mediating variables to explore the relationship between classroom IEQ and student learning satisfaction in the future is highly recommended. Student motivation could be added as the mediator or moderator to investigate the effect between these two variables.

\section{Corresponding Author}

Mohd Hazwan Mohd Puad (PhD) is a senior lecturer at the Faculty of Educational Studies, Universiti Putra Malaysia (UPM), Serdang, Selangor, Malaysia. Email: hazwan@upm.edu.my

\section{References}

Zuhairi, A. J. A., \& Puad, M. H. M. (2016). Influence of Classroom Indoor Environmental Quality 
INTERNATIONAL JOURNAL OF ACADEMIC RESEARCH IN PROGRESSIVE EDUCATION AND

DEVELOPMENT

Vol. 8, No. 4, 2019, E-ISSN: 2226-6348 @ 2019 HRMARS

on Student Satisfaction. Graduate Research in Education (GREDUC) 2016 Seminar Proceedings, Universiti Putra Malaysia, Malaysia. Retrieved from http://conference.upm.edu.my/greduc

Amirul, N. J., Ahmad, C. N. C., Yahya, A., Abdullah, M. F. N. L., Adnan, M., \& Noh, N. M. (2013). The physical classroom learning environment, presented at 2nd International Higher Education Teaching and Learning Conference 2013.

Awang, N. A., Mahyuddin, N., \& Kamaruzzaman, S. N. (2015). Indoor Environmental Quality Assessment and Users Perception in Meru Secondary School (SMK Meru). Journal of Building Performance, 6(1), 105-115.

Bolliger, D. U., \& Martindale, T. (2004). Key factors for determining student satisfaction in online courses. International Journal, 3, 61-67.

Borden, V. (1995). Segmenting student markets with a student satisfaction and priorities survey. Research in Higher Education, 36(1), 73 - 88.

Chang, I. Y., \& Chang, W. Y. (2012). The effect of student learning motivation on learning satisfaction. International Journal of Organizational Innovation, 4(3), 281.

Cheryan, S., Ziegler, S. A., Plaut, V. C., \& Meltzoff, A. N. (2014). Designing classrooms to maximize student achievement. Policy Insights from the Behavioral and Brain Sciences, 1(1), 4-12.

Cotton, S. J., Dollard, M. F., \& Jonge, D. J. (2002). Stress and student job design: Satisfaction, wellbeing, and performance in university students. International Journal of Stress Management, 9(3), 147-162.

Chang, K. Y. (2011). Factors Affecting Student Satisfaction in Different Learning Deliveries (Doctoral Dissertation). Available form ProQuest Dissertations and Theses database. (UMI Number: 3602440)

Chokor, A. (2015). Evaluating the Performance of Leadership in Energy and Environmental Design (LEED) Certified Facilities using Data-Driven Predictive Models for Energy and Occupant Satisfaction with Indoor Environmental Quality (IEQ) (Doctoral dissertation). Available form ProQuest Dissertations and Theses database. (UMI No. 1604803)

Choi, S., Guerin, D. A., Kim, H. Y., Brigham, J. K., \& Bauer, T. (2014). Indoor environmental quality of classrooms and student outcomes: A path analysis approach. Journal of Learning Spaces, 2(2), 2013-14.

Chiang, C. M., \& Lai, C. M. (2008). Acoustical environment evaluation of Joint Classrooms for elementary schools in Taiwan. Building and Environment, 43(10), 1619-1632.

Durodola, O., \& Ajayi, C. (2015). Comparative Analysis of Students' Satisfaction with Classroom Facilities in Nigerian Private Universities. Journal of Studies in Education, 5(4), 242257.Department of Statistics Malaysia. (2019). Labour Force \& Social Statistics. Retrieved from https://www.dosm.gov.my/v1/index.php?r=column/ctwoByCat\&parent_id=123\&menu _id=U3VPMIdoYUxzVzFaYmNkWXZteGduZz09

Fisk, W. J. (2002). How IEQ affects health, productivity. ASHRAE Journal, 44(5), 56.

Flammger, D. M. (1991). Nontraditional students and postsecondary school satisfaction (Master's thesis). Retrieved form ERIC Document Reproduction Service. (No. ED 362077). Huang, S. Y. (2014). Relevance of IT integration into teaching to learning satisfaction and learning effectiveness. World Journal of Education, 4(2), 1. 
Vol. 8, No. 4, 2019, E-ISSN: 2226-6348 @ 2019 HRMARS

Gu, Y. (2011). The impacts of real-time knowledge based personal lighting control on energy consumption, user satisfaction and task performance in offices (Doctoral dissertation, Carnegie Mellon University Pittsburgh, PA). Retrieved form http://repository.cmu.edu/dissertations/54

Hatcher, L., Kryter, K., Prus, J. S., \& Fitzgerald, V. (1992). Predicting college student satisfaction, commitment, and attrition from investment model constructs. Journal of Applied Social Psychology, 22(16), 1273-1296.

Hanssen, T. E. S., \& Solvoll, G. (2015). The importance of university facilities for student satisfaction at a Norwegian University. Facilities, 33(13/14), 744-759.

Jurado, S. R., Bankoff, A. D., \& Sanchez, A. (2014). Indoor air quality in Brazilian universities. International Journal of Environmental Research and Public Health, 11(7), 7081-7093.

Kabanshi, A., Wigo, H., Ljung, R., \& Sorqvist, P. (2016). Human perception of room temperature and intermittent air jet cooling in a classroom. Indoor and Built Environment, 0(0), 1-10.

Katz, D. \& Kahn, R. L. (1978). The Social Psychology of Organizations. Oxford, England: Wiley.

Klatte, M., Bergstroem, K., \& Lachmann, T. (2013). Does noise affect learning? A short review on noise effects on cognitive performance in children. Frontiers in Psychology, 4, 1-6.

Ko, W. H., \& Chung, F. M. (2014). Teaching Quality, Learning Satisfaction, and Academic Performance among Hospitality Students in Taiwan. World Journal of Education, 4(5), 11.

Lechner, N. (2014). Heating, cooling, lighting: Sustainable design methods for architects. New York: John Wiley \& Sons.

Puerto, L. D. C. (2009). Relationship between the physical characteristics of higher educational facilities and student attitudes about their graduate school programs (Doctoral dissertation, Saint Louis University). Available from ProQuest Dissertations and Thesis database. (UMI Number: 3383214)

Lee, Y. (2007). The relationship between indoor environmental quality and worker satisfaction and performance in leadership in energy and environmental design (LEED ${ }^{\circledR}$ ) certified buildings. (Doctoral dissertation). Available from ProQuest Dissertations and Thesis database. (UMI No. 3292959)

Lewinski, P. (2015). Effects of classrooms' architecture on academic performance in view of telic versus paratelic motivation: a review. Frontiers in Psychology, 6 (746), 1-5.

Mendell, M. J., \& Heath, G. A. (2005). Do indoor pollutants and thermal conditions in schools influence student performance? A critical review of the literature. Indoor Air, 15(1), 2752.

Ministry of Education. (2019). Laporan Kajian Pengesanan Graduan. Retrieved from https://www.moe.gov.my/en/muat-turun/laporan-dan-statistik/pendidikantinggi/laporan-kajian-pengesanan-graduan

Martin, C. L. (1988). Enhancing children's satisfaction and participation using a predictive regression model of bowling performance norm. The Physical Education, 45(4), 196-209.

McCreery, J., \& Hill, T. (2005). Illuminating the classroom environment. School Planning and Management, 44(2), 1-3.

Schreiner, L. A., \& Juillerat, S. L. (1994). The student satisfaction inventory. Iowa City, IA: NoelLevitz

Shell, S. (2015). Effect of the physical environment on teacher satisfaction with indoor 
Vol. 8, No. 4, 2019, E-ISSN: 2226-6348 @ 2019 HRMARS

environmental quality in early learning schools (Master's Thesis). Retrieved from http://digitalcommons.unl.edu/archengdiss/34/

Samani, S. A., \& Samani, S. A. (2012). The Impact of Indoor Lighting on Students' Learning Performance in Learning Environments: A knowledge internalization perspective. International Journal of Business and Social Science, 3(24), 127-146.

Schneider, M. (2002). Do School Facilities Affect Academic Outcomes? National Clearinghouse for Educational Facilities: National Institute of Building Sciences.

Singh, P. (2013). Indoor environmental quality \& student health and performance: A conceptual review. International Journal of Physical and Social Sciences, 3(7), 96.

Tanner, C. K. (2009). Effects of school design on student outcomes. Journal of Educational Administration, 47(3), 381-399.

Tough, A. (1982) Some major reasons for learning. (Eric Document Reproduction Service, No. ED. 033-251)

United Nations Educational, Scientific and Cultural Organization. (2019). What UNESCO does on Education for Sustainable Development. Retrieved from https://en.unesco.org/themes/education-sustainable-development/what-UNESCOdoes.

Vidalakis, C., Sun, M., \& Papa, A. (2013). The quality and value of higher education facilities: a comparative study. Facilities, 31(11/12), 489-504.

Wark, K. \& Warner, C. F. (1981). Air Pollution, Its Origin and Control. New York: Harper Collins.

Wu, J. H., Hsia, T. L., Liao, Y. W., \& Tennyson, R. (2008). What determinates student learning satisfaction in a blended e-learning system environment? PACIS 2008 Proceedings, 149.

Yang, Z., Becerik-Gerber, B., \& Mino, L. (2013). A study on student perceptions of higher education classrooms: Impact of classroom attributes on student satisfaction and performance. Building and Environment, 70, 171-188.

Zannin, P. H. T., Passero, C. R. M., \& Zwirtes, D. P. Z. (2012). Assessment of acoustic quality in classrooms based on measurements, perception and noise control, reduction and cancellation solutions in engineering, D. Siano (Ed.). Available from http://www.intechopen.com/books/noise-control-reduction-and-cancellationsolutions-in-engineering/assessment-of-acoustic-quality-in-classrooms-based-onmeasurements-perception- and-noise-control

Zannin, P. H. T., and Zwirtes, D. P. Z. (2009). Evaluation of the acoustic performance of classrooms in public schools. Appl. Acoust. 70, 625-635. 